\title{
Patient Satisfaction Service Experience Influence at Pertiwi Special Hospital for Mothers and Children, South Sulawesi
}

\author{
Nurfitriani $^{1}$, Mene Paradilla ${ }^{1}$, Ainun Jariyah ${ }^{1}$ \\ Corresponding Email: nurfitnur2112@gmail.com \\ ${ }^{1}$ Hospital Administration Study Program, Faculty of Health Sciences, Cokroaminoto \\ University Makassar, Indonesia
}

Received: December 29, 2021

Received in Revised: January 20, 2022

Accepted: January 28, 2022

\begin{abstract}
Patient satisfaction must be obtained in order to compete in the hospital sector, which tends to develop at a faster rate than current demands. The purpose of this research is to examine if Service Experience has an influence on patient satisfaction at the Mother and Child Regional Special Hospital in South Sulawesi Province's inpatient installation. This is a quantitative study that combines an observational design with a cross sectional study design. Using the Accidental Sampling technique, the samples in this research consisted of 65 respondents who were inpatients at the Mother and Child Hospital of the Motherland. The findings indicated that service experience as measured by functional clues, mechanic clues, humanic cues, and perceived value all had an influence on patient satisfaction. It is advised that all officers, including management and staff, maintain the dimensions of a positive service experience. Ascertain that expectations, wishes, and requirements are met in accordance with hospital standards, particularly in the dimensions of functional and humanic signals, by enhancing the sensitivity of nurses in handling/care that may assist with complaints. Patients, there has to be an increase in customer value initiatives so that patients experience a sense of pride while seeking care at the hospital.
\end{abstract}

Keywords: Service Experience, Functional Clues, Mechanic Clues, Humanic Clues

\section{Introduction}

Hospitals are a vital element of health care systems that undergo transformations in their value orientation and way of thinking. The hospital's basic mission as a location for treatment has evolved into a cohesive service endeavor for the whole community, including promotional, preventative, curative, and rehabilitative components (Menkes, 2009). To survive and succeed in a quickly changing and competitive market, hospitals must shift their management paradigm toward a consumer-centric perspective.

Approaching service quality and customer happiness as a strategy is critical and cannot be overlooked. All hospital services, including inpatient treatment units, must adhere to these standards (Zarei et al., 2015). The quality of health care services in hospitals must be quantified, specifically by quantifying each dimension of service quality in order to ascertain the amount of patient satisfaction supplied by services Pohan in (Az-Zahroh, 2017).

Patient satisfaction is a critical component of hospital success (Koné \& Wodchis, 2013). Patient satisfaction refers to the degree to which health care professionals meet patients' expectations, objectives, and preferences (Huei et al., 2015). Increased patient satisfaction with treatment encourages patients to follow their doctor's prescriptions, to be more loyal, to spread good word 
of mouth, to minimize patient complaints, to generate greater revenues, more patient returns, and more patient referrals (Zarei et al., 2015).

A service experience is an impression or perception formed throughout the course of a customer's consumption of a product or service. According to him, sensory and emotional cues determine the service experience. Otto \& Ritchie (1996) describe service experience as a psychological environment comprised of consumers' own emotions and feelings while consuming services. Meanwhile, Specht et al. (2007) assert that experience is a subjective internal reaction to any direct encounter between consumers and service providers. This happens at all points of contact between customers and service providers. The client's experience will be etched in his or her mind as a type of consumer review of the service obtained.

According to Bagdare \& Jain (2013), service experience is the sum of cognitive, emotional, sensory, and behavioral reactions elicited by a sequence of integrated interactions with service stakeholders, processes, and the service environment throughout service use. It demonstrates, based on multiple prior study findings, that service experience has a significant impact on patient satisfaction (Guo, 2012; Retnaningsih et al., 2017). While Haeckel et al. (2003) and Leonard (2008) said that service hints influence satisfaction through forming views about individual service experiences.

The Mother and Child Regional Special Hospital for the Motherland is a specialized hospital that provides care for mothers and children, including pregnant women and newborns, whose care requires a lengthy and continuous period from the start of pregnancy until the baby receives advanced services such as immunizations and vaccines.

Patient satisfaction at the Mother and Child Mother Regional Special Hospital's inpatient installation averaged 82.62 percent from 2016 to 2018, which fell short of the national requirements established (Ministry of Health Standards No. 129 of 2008 of 90 percent). Patient satisfaction is believed to have an effect on hospital staff loyalty and service quality.

Based on the difficulties and findings of earlier research, this study was done to determine the influence of service experience on patient satisfaction at the Mother and Child Regional Special Hospital's Inpatient Installation (RSKD). To continue to enhance the quality of services and to increase patient visits to health care facilities.

\section{Methods}

This research was conducted at the Mother and Child Special Hospital of the Motherland of South Sulawesi Province. The type of research conducted is quantitative research using an observational study with a Cross Sectional Study approach. The population in this study were all patients in the Inpatient Installation of the Mother and Child Special Hospital of the Motherland of South Sulawesi Province. Sampling using the Accidental Sampling technique, so the sample in this study amounted to 65 people.

The instrument used in data collection is a questionnaire, regarding the independent variable in the form of service experience while the dependent variable is the patient satisfaction variable. Univariate analysis was conducted to obtain an overview of the research problem by describing each variable used in the study and the characteristics of the respondents. Univariate analysis consisted of descriptive analysis of respondents' characteristics, descriptive analysis of research variables and crosstabulation analysis between respondents' characteristics and research variables. Bivariate analysis was carried out to see the effect of two variables, namely between 
the independent variables and the dependent variable. The statistical test used was the chi square test and the multivariate analysis used logistic regression analysis.

\section{Results and Discussion}

The frequency distribution is shown in Table 1.

Table 1. Frequency Distribution of Common Characteristics of Respondents

\begin{tabular}{|c|c|c|}
\hline \multirow{2}{*}{$\begin{array}{c}\text { Characteristics of } \\
\text { Respondents }\end{array}$} & \multicolumn{2}{|c|}{ RSIA Pertiwi } \\
\hline & (n) & $(\%)$ \\
\hline $15-20$ & - & - \\
\hline $21-25$ & 16 & 24.6 \\
\hline $26-30$ & 38 & 58.5 \\
\hline $31-35$ & 7 & 10.8 \\
\hline $36-40$ & 4 & 6.2 \\
\hline $41-45$ & - & - \\
\hline \multicolumn{3}{|l|}{ Gender } \\
\hline Man & - & - \\
\hline Woman & 65 & 100 \\
\hline \multicolumn{3}{|l|}{ Education } \\
\hline Not school & 7 & 10.8 \\
\hline Elementary School/Equivalent & 17 & 26.2 \\
\hline Junior School & 26 & 40.0 \\
\hline $\begin{array}{c}\text { High School/Vocational } \\
\text { School }\end{array}$ & 9 & 13.8 \\
\hline Academy/Higher Education & 6 & 9.2 \\
\hline \multicolumn{3}{|l|}{ Work } \\
\hline Civil Servant & 7 & 10.8 \\
\hline Private Employees & 18 & 27.7 \\
\hline Merchant & 1 & 1.5 \\
\hline House Wife & 36 & 55.4 \\
\hline Other & 3 & 4.6 \\
\hline Total & 65 & 100 \\
\hline
\end{tabular}

\section{Source: Primary Data}

According to the sample characteristics at the Mother and Child Mother Regional Special Hospital, the majority of respondents are in the 26-30 year age bracket, accounting for 38 respondents or 58.5 percent; the majority of respondents are female, accounting for 65 respondents or 100 percent. According to the features of the previous level of education, the most respondents had an SMP/SLTA education, totaling 26 respondents or $40 \%$, and according to the characteristics of the employment, the most respondents were domestic workers, totaling 36 respondents or 55.4 percent.

Table 2. Distribution of Respondent Frequency Based on Research Variables

\begin{tabular}{|c|c|c|c|c|c|c|c|}
\hline \multirow{2}{*}{$\begin{array}{c}\text { Functional } \\
\text { Clues }\end{array}$} & \multicolumn{3}{|c|}{ Patient Satisfaction } & \multicolumn{2}{c|}{ Total } & \multirow{2}{*}{$\boldsymbol{P}$} \\
\cline { 2 - 7 } & \multicolumn{2}{|c|}{ Good } & \multicolumn{2}{|c|}{ Less } & \multicolumn{2}{|c|}{} \\
\cline { 2 - 7 } & $\mathbf{n}$ & $\mathbf{\%}$ & $\mathbf{n}$ & $\mathbf{\%}$ & $\mathbf{n}$ & $\boldsymbol{\%}$ & \\
\hline Good & 7 & 70 & 3 & 30 & 10 & 100 & .000 \\
\hline Less & 5 & 9.1 & 50 & 90.9 & 55 & 100 & \\
\hline
\end{tabular}




\begin{tabular}{|c|c|c|c|c|c|c|c|}
\hline Total & 12 & 18.5 & 53 & 81.5 & 65 & 100 & \\
\hline Mechanic & \multicolumn{4}{|c|}{ Patient Satisfaction } & \multirow{2}{*}{\multicolumn{2}{|c|}{ Total }} & \multirow[t]{3}{*}{$P$} \\
\hline Clues & \multicolumn{2}{|c|}{ Good } & \multicolumn{2}{|c|}{ Less } & & & \\
\hline & $\mathbf{n}$ & $\%$ & $\mathbf{n}$ & $\%$ & $\mathbf{n}$ & $\%$ & \\
\hline Good & 7 & 77.8 & 2 & 22.2 & 9 & 100 & \multirow[t]{3}{*}{.000} \\
\hline Less & 5 & 8.9 & 51 & 91.1 & 56 & 100 & \\
\hline Total & 12 & 18.5 & 53 & 81.5 & 65 & 100 & \\
\hline \multirow{3}{*}{$\begin{array}{c}\text { Humanist } \\
\text { Clues }\end{array}$} & \multicolumn{4}{|c|}{ Patient Satisfaction } & \multirow{2}{*}{\multicolumn{2}{|c|}{ Total }} & \multirow[t]{3}{*}{$\boldsymbol{P}$} \\
\hline & \multicolumn{2}{|c|}{ Good } & \multicolumn{2}{|c|}{ Less } & & & \\
\hline & $\mathbf{n}$ & $\%$ & $\mathbf{n}$ & $\%$ & $\mathbf{n}$ & $\%$ & \\
\hline Good & 7 & 63.6 & 4 & 36.4 & 11 & 100 & \multirow[t]{3}{*}{.000} \\
\hline Less & 5 & 9.3 & 49 & 90.7 & 54 & 100 & \\
\hline Total & 12 & 18.5 & 53 & 81.5 & 65 & 100 & \\
\hline
\end{tabular}

Source: Primary Data

Table 2 summarizes respondents' ratings of the study factors as a percentage. With a p value of 0.0000 .05 for the functional clues variable, it can be stated that the functional clues variable has an influence on patient satisfaction. The influence of the mechanic clues variable on the patient satisfaction variable, where the value of $p=0.0000 .05$ indicates that the mechanic clues variable has an effect on patient satisfaction in inpatient facilities. The impact of the humanic clues variable on the patient satisfaction variable, where the value of $p=0,0000,05$ indicates that the humanic clues variable has an effect on patient satisfaction in inpatient settings.

Table 3. The Simultaneous Effect of Service Experience on Patient Satisfaction at The Hospitalization Installation of Mother and Child Hospital of South Sulawesi Province

\begin{tabular}{|c|c|c|c|c|c|}
\hline Variable & B & S.E. & Wald & Sig. & $\operatorname{Exp(B)}$ \\
\hline Functional Clues & 2.335 & 1.174 & 3.954 & .047 & 10.327 \\
\hline Mechanic Clues & 2.580 & 1.281 & 4.056 & .044 & 13.197 \\
\hline Humanic Clues & 2.513 & 1.154 & 4.740 & .029 & 12.339 \\
\hline
\end{tabular}

Source: Primary Data

According to Table 3, the results of the logistic regression test of the functional clues, mechanic clues, and humanic clues variables on patient satisfaction in the Inpatient Installation of the Mother and Child Regional Special Hospital, South Sulawesi Province, revealed that the variable with the greatest influence was humanic clues with a $p$ value of 0.0290 .05 , implying that the humanic clues variable has a greater influence. Humanic hints has a positive sign coefficient and an odd ratio of 12,339 for its odd ratio. This study indicates that for every rise or decrease in one unit of evaluation of humanic cues, the chance of the responder giving a negative assessment of patient satisfaction increases by 12,339 times as compared to producing a favorable assessment. This figure indicates a 2,513-fold disparity between excellent and poor opportunities.

The term "service experience" refers to the collection of encounters between consumers and service providers. Helkkula \& Kelleher, (2010) defines service experience as the "heart" of the service delivered and the design of the service. Service experience as the impression or perception formed by a product or service during the customer's consumption of it. Sensory and emotional cues impact the service experience. 
Functional clues are values that indicate the technical, reliable, and functional quality of a service. Functional hints might be seen as indicators of a service provider's competency. Functional Clues / functional clues are at the heart of every service because they direct customers to a service provider to resolve their problems; in other words, it is through these instructions that the service provider can meet its customers' expectations due to the functional aspects of the service that provide the expected core solution. clients (Berry et al., 2006). According to Bhandari \& Javakhadze (2017), clients use their brain logic circuits to encode functional instructions relating to the dependability / reliability and function of service providers a survey done on why consumers transfer service providers, 44 percent of the sample switched due to core service failures.

The logistic regression test findings indicate that $\mathrm{p}=0.0000 .05$, indicating that the functional clues variable has an influence on patient satisfaction in the inpatient installation of a special hospital for women and children in the province of South Sulawesi. This study supports functional hints have an influence on the service experience and customer satisfaction. Fulfilling consumer expectations based on functional indications generates a feeling of pleasure in customers, which encourages them to utilize the product or service again. Because functional clues have an effect on a customer's cognitive or calculative perception of service quality, understanding and managing them effectively is critical to meeting customer service expectations, as functionality provides core solutions that customers purchase but typically falls short of exceeding customer service expectations.

Mechanic cues are circumstances in the service environment that include the senses of sight, smell, and taste, as well as the service institution's physical appearance. While function hints emphasize the service's dependability, mechanic clues emphasize the service's sensory appearance. Mechanical cues derived from inanimate items will be used to create a physical representation of intangible services. Customers cannot directly inspect service providers' competency, but they may see current mechanical instructions (Berry et al., 2006).

Mechanical signals are critical in creating a favorable initial impression with clients. Because the consumer purchases the service before to experiencing it. The influence on customer service expectations is one of the first impressions that mechanical cues make. The customer's subjective assessment of service quality is made in comparison to the customer's expectations for the service. The correct mechanical leads assist the business in attracting the kind of clients it desires. Mechanical instructions are critical for services where consumers spend extended periods of time in facilities, such as airlines, hotels, and hospitals (Berry et al., 2006).

The logistic regression test findings indicate that $\mathrm{p}=0.0000 .05$, indicating that the mechanic clues variable has an effect on patient satisfaction in the inpatient installation of a special hospital for women and children in the province of South Sulawesi. This study corroborates Retnaningsih et al. (2017) findings that mechanic cues have an influence on customer satisfaction at A.M Parikesit Hospital's Inpatient Installation. It is mentioned that if the client perceives the service environment to be in excellent condition, which includes features of sight, smell, and taste, or the physical look of the service institution, the degree of satisfaction will also be in good condition. Mechanical indications are critical in creating a favorable first impression with consumers, since clients purchase services prior to experiencing them. The influence on customer service expectations is one of the first impressions that mechanical cues make. Mechanic cues refer to the circumstances of the service environment that include features of sight, smell/smell and taste, as well as physical appearance, or may be thought of as hints released by items. 
Humanic cues are characteristics of service providers' behavior and appearance, such as their manner of speaking and body language, their voice intonation, their degree of excitement, and their attire. Officers' conduct has an effect on customer satisfaction because consumers assess encounters holistically, and the impressions formed while receiving services are critical in achieving customer happiness (Turkay \& Sengul, 2014). The majority of responders had a favorable opinion of humanic hints. As reported by responders to open study questions, physicians who treat patients are always nice and polite in their greetings to patients and families. Additionally, nurses were described as constantly sensitive to the patient's condition, courteous, and always there if assistance was required.

The findings of the logistic regression test indicate that $p=0.0000 .05$, indicating that the humanic clues variable has an effect on patient satisfaction in the inpatient installation of a special hospital for mothers and children in the province of South Sulawesi. This study corroborates Retnaningsih et al. (2017) result that humanic cues impact customer satisfaction at the A.M Parikesit Hospital's Inpatient Installation. It is claimed that when clients see service personnel with positive attitudes and behaviors, they would feel pleased (Retnaningsih et al., 2017).

According to Hartline in (Mattila \& Enz, 2002), the attitude and conduct of service providers are critical to the client assessment process. Humanistic cues are vital for surpassing customer expectations when it comes to employee-intensive interactive services, since customer care is critical to the service experience. Employee interactions provide the finest chance to show a dedication to service to consumers. Employee-generated humanic cues are most prevalent in interactions between customers and service providers. Employee interactions throughout the service experience create chances to develop emotional connections with consumers, exceeding their expectations, strengthening trust, and deepening their commitment (Berry et al., 2006)

\section{Conclusion}

The researchers concluded the following based on the study's findings: Service experience based on functional clues variables, mechanical clues variables, humanic clues variables that influence patient satisfaction, and humanic clues variables that have the greatest impact on patient satisfaction at the Special Hospital for Mothers Region's inpatient installation and Anak Pertiwi, South Sulawesi Province. It is recommended that every officer, both management and staff, maintain the dimensions of a positive service experience. Attempt to meet the expectations, desires, and needs of patients in accordance with hospital standards, particularly in the dimensions of functional and humanic clues, by increasing the sensitivity of nurses in handling/care that can assist with complaints. Patients, there has to be an increase in customer value initiatives so that patients experience a sense of pride while seeking care at the hospital.

\section{References}

Az-Zahroh, T. N. (2017). Pengaruh Mutu Pelayanan Kesehatan Terhadap Tingkat Kepuasan Pasien Rawat Inap di Ruang Dewasa Umum Rumah Sakit X Kabupaten Gresik. PSIKOSAINS (Jurnal Penelitian dan Pemikiran Psikologi), 12(2), 99-111.

Bagdare, S., \& Jain, R. (2013). Measuring retail customer experience. International Journal of Retail \& Distribution Management.

Berry, L. L., Wall, E. A. \& Carbone, L. P., (2006). Service Clues and Customer Assessment of the Service Experience: Lessons from Marketing Three Types of Clues. , pp.43-56. 
Bhandari, A., \& Javakhadze, D. (2017). Corporate social responsibility and capital allocation efficiency. Journal of Corporate Finance, 43, 354-377.

Guo, M. (2012). Service Experience from Customers Point of view.

Haeckel, S. H., Carbone, L. P., \& Berry, L. L. (2003). How to Lead the Customer Experience. Marketing Management, 12(1), 18-23.

Haeckel, S. H., Carbone, L. P., \& Berry, L. L. (2003). How to lead the customer experience. Marketing Management, 12(1), 18-18.

Helkkula, A., \& Kelleher, C. (2010). Circularity of customer service experience and customer perceived value. Journal of customer behaviour, 9(1), 37-53.

Huei, C. T., Mee, L. Y., \& Chiek, A. N. (2015). A Study of Brand Image, Perceived Service Quality, Patient Satisfaction and Behavioral Intention among the Medical Tourists, Global Journal of Business and Social Science Review. 2(1).

Koné Péfoyo, A. J. \& Wodchis, W. P. (2013) 'Organizational performance impacting patient satisfaction in Ontario hospitals: a multilevel analysis.', BMC research notes, 6, p. 509.

Leonard, K. L. (2008). Is patient satisfaction sensitive to changes in the quality of care? An exploitation of the Hawthorne effect. Journal of health economics, 27(2), 444-459.

Mattila, A. S., \& Enz, C. A. (2002). The role of emotions in service encounters. Journal of Service research, 4(4), 268-277.

Otto, J. E., \& Ritchie, J. B. (1996). The service experience in tourism. Tourism management, 17(3), 165-174.

Retnaningsih, D., Aini, D. N., \& Yulianti, I. (2017). Kepuasan keluarga pasien di ruang ICU rumah sakit permata medika semarang. Jurnal Kesehatan Kusuma Husada.

Şengül, S., \& Türkay, O. (2016). Akdeniz mutfak kültürünün gastronomi turizmi bağlamında değerlendirilmesi. Journal of Tourism and Gastronomy Studies, 4(1), 86-99.

Specht, N., Fichtel, S., \& Meyer, A. (2007). Perception and attribution of employees' effort and abilities: The impact on customer encounter satisfaction. International Journal of Service Industry Management.

Zarei, E., Daneshkohan, A., Khabiri, R., \& Arab, M. (2015). The effect of hospital service quality on patient's trust. Iranian Red Crescent Medical Journal, 17(1) 